\title{
OBITUARY
}

\section{Dr. OtTo William Samson}

Otto Samson, who died aged 76 on 12 March 1976, was one of those German scholars from whose arrival in the 1930's Britain benefited so greatly. After a rigorous classical education at Freiburg-im-Breisgau, Berlin, Munich, and Hamburg, he had become Assistant Keeper at the Hamburg Museum of Ethnography from 1928-30 and Keeper from 1930-3. During 1931-2 he had travelled widely in China collecting specimens for the museum. Hamburg at that time with its fine collections was a lively centre of intellectual life and a brilliant career appeared to await him. But the Nazi blight fell upon Germany and in 1933 he came to England.

Although it was long before he gained a permanent post, he was fortunately able to re-enter academic life and thus make his own unique contribution. He was first absorbed into the Galton Laboratory in the University of London where he worked on physical anthropology until the outbreak of war in 1939. Between 1935 and 1937 he had travelled in India, Burma, and Tibet, where he collected the objects with which so many of us later became familiar. In 1939 he was made a temporary Assistant Keeper in the Ethnographical Department of the British Museum where he remained until 1947. He then became Curator of the Horniman Museum at Forest Hill, London, a post which he held until his retirement in 1965. In spite of its sparse financial resources, he changed an old-fashioned institution into one of the best ethnographic museums in Europe and in particular built up its famous collection of musical instruments. In 1949 he had joined the Royal Asiatic Society and from 1970 to 1974 was a conscientious member of Council.

I myself, after retiring from the Indian Civil Service and before joining the Victoria and Albert Museum in 1949, met Otto in 1948. I was then collecting materials for the exhibition "Forty Thousand Years of Modern Art" sponsored by the Institute of Contemporary Art. I sensed at once our common enthusiasm for Indian art at the popular level and Otto invited me home to see his private collection. What a spectacle it was! Here, in stimulating juxtaposition, were objects from the entire Eastern world-pots, textiles, paintings, sculptures, bronzes, masks. My eye was caught by two examples of medieval Orissan sculpture showing lovers in wild embraces, a tall wooden female figure, also Orissan, and fondly termed "Radha", a framed picture of Srinathji, a Kalighat painting of a top-hatted English judge presiding at a murder trial, a unique Nepalese tanka displaying with superlative elegance the miniature style of Pala painting on a grandly enlarged scale. There was seemingly no end to Otto's compulsive zest for salvaging and hoarding anything that had a whiff of the primitive, popular or Oriental. Although he valued their aesthetic qualities, it was their roots in popular fancy that excited him. He could see similarities of thought, feeling, symbolism, and style stretching all over Asia and with the eagerness of the born explorer, adventurer, and "big-game hunter", he included them all in his fabulous "bag".

As I got to know him better, I realized what an extraordinary scholar he was and also what a charming friend. His library was enormous, his knowledge encyclopaedic. There was hardly anything he did not know about remote Asia and its customs. Although, to use a phrase of Cyril Connolly's, he was "an ever-reader"" and "a never-writer", this was a fortunate asset. Not for him the blistering review, the belligerent article or a monograph crackling with thunder! Otto was quieter and more subtle. He believed in the still, small voice, in calm and intimate oral discussions in which his dry sense of humour, flair for witticisms-he had, at one time, written extremely funny light verse-and his stock of recondite information could expand like "Japanese flowers" in water. There was also a benign and loving strain in his character so that, even when riled by the treachery of trusted associates, he could shrug his sadness off with a wry smile. He was for 30 years a close friend of Arthur Waley, and realizing, as I did, how formidable Arthur could be, yet so touchingly 
loyal and appreciative, I can understand how strong a spell Otto must have cast to win Arthur's allegiance.

Sotto voce as Otto's conversation might seem to be at social gatherings, private views or at the Society's meetings, it was at his fiat in Taymount Rise that he truly blossomed. It was here that he and his wife, Elizabeth, frequently gave parties, bringing together with sensitive skill people from widely differing spheres but with a common interest in art, archaeology or ethnography. Many of us will long remember those buffet suppers with their delicious food and drink over which Elizabeth presided with her gay attire, chic smartness, and unfailing vivacity. Her quick-witted talk complemented Otto's quietness and between them they radiated happiness. Chancing one Sunday afternoon to be at Hampton Court with my wife-we had gone there to view the Mantegnas-who should we see but Otto and Elizabeth! They were dressed for the occasion, dashingly smart, sauntering together down one of the walks, arm in arm, the very epitome of loving gallantry. Otto's massive and pioneering contributions to modern ethnology will long be admired but anecdotes such as these may ensure that he will always be fondly and proudly recalled.

W. G. ARCHER. 